\title{
Impact of maternal subclinical hypothyroidism on the neurocognitive development of children; a systematic review
}

Fahimeh Ramezani Tehrani ${ }^{1}$, Sima Nazarpour ${ }^{2,3}$, Fereidoun Azizi ${ }^{4}$

${ }^{1}$ Professor, Reproductive Endocrinology Research Center, Research Institute for Endocrine Sciences, Shahid Beheshti University of Medical Sciences, Tehran, Iran. ORCID ID: 0000-0002-4609-065X.

${ }^{2}$ Assistant Professor, Department of Midwifery, Faculty of Medical Sciences, Varamin-Pishva Branch, Islamic Azad University, Tehran, Iran. (Corresponding Author), Tel: 021 -22 4325 00, Email: snazarpour@ gmail.com. ORCID ID: 00000001-7972-2513.

${ }^{3}$ Reproductive Endocrinology Research Center, Research Institute for Endocrine Sciences, Shahid Beheshti University of Medical Sciences, Tehran, Iran.

${ }^{4}$ Professor, Endocrine Research Center, Research Institute for Endocrine Sciences, Shahid Beheshti University of Medical Sciences, Tehran, Iran. E-mail: azizi@endocrine.ac.ir. ORCID ID: 0000-0002-6470-2517.

\begin{abstract}
Background and Aim: Thyroid hormones play an important role in the development and maturation of the central nervous system before and after birth. There is not enough scientific evidence about the effect of subclinical hypothyroidism on neurocognitive development in offsprings. This systematic review was conducted to assess the effect of maternal subclinical hypothyroidism on the neurocognitive development of children.

Materials and Methods: In this systematic review, the PubMed, Web of Science and Scopus data bases as well as SID, Irandoc, and Magiran (Persian databases) were searched for the English and Persian related articles using appropriate keywords. In the current systematic review, of 411 records obtained through primary searching, 9 eligible cohort studies were evaluated. The quality of articles was assessed using the Newcastle-Ottawa scale.

Results: Different studies have used different scales to evaluate the neurodevelopment of offsprings with different age ranges at the time of assessment. The results of 5 of the 9 selected studies indicated a lower IQ and neurodevelopment scores in the children born to mothers with subclinical hypothyroidism than in those born to euthyroid mothers. In four studies, there was no difference in neurodevelopment scores in the offsprings between the two groups.

Conclusions: There is no consensus about the impact of maternal subclinical hypothyroidism on neonatal neurodevelopment. Considering the limitations of the current methods for assessment of neurocognitive development of children, use of new biochemical parameters for precise and early evaluation of neurocognitive development in offsprings should be taken into consideration.
\end{abstract}

Keywords: Subclinical Hypothyroidism, Pregnancy, Neurocognitive, Development, Children, Systematic Review

Received: Sep 18, 2019

Accepted: Jan 19, 2020

How to cite the article: Fahimeh Ramezani Tehrani ,Sima Nazarpour, Fereidoun Azizi . Impact of maternal subclinical hypothyroidism on the neurocognitive development of children; a systematic review.⿱口́̉SJKU 2021;26(2):41-56.

Copyright (c) 2018 the Author (s). Published by Kurdistan University of Medical Sciences. This is an open access article distributed under the terms of the Creative Commons Attribution-Non Commercial License 4.0 (CCBYNC), where it is permissible to download, share, remix, transform, and buildup the work provided it is properly cited. The work cannot be used commercially without permission from the journal 


\section{تأثير هيبوتيروئيدى تحت بالينى مادر بر تكامل عصبى شناختى كودكان، مرور سيستماتيك}

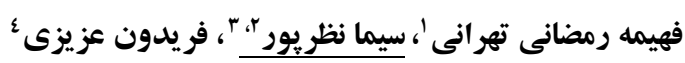

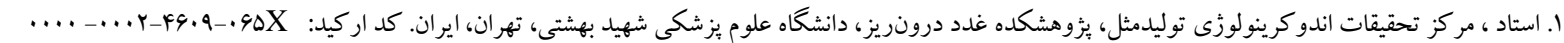

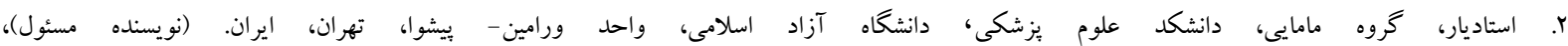

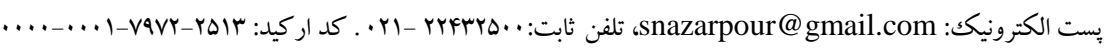

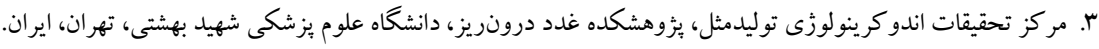

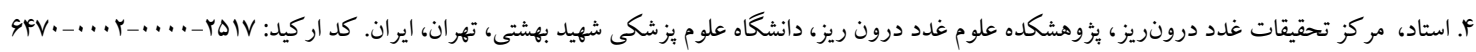

زمينه و هدف: هورمونهاى تيروئيد اثر مهمى در تكامل و بلوغ سيستم عصبى مركزى قبل و بعد از تولد دارند. شواهد علمى

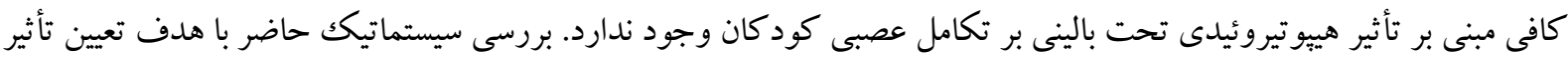

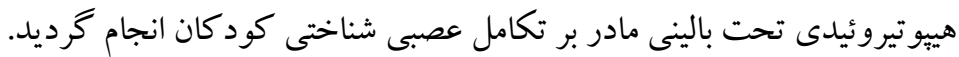

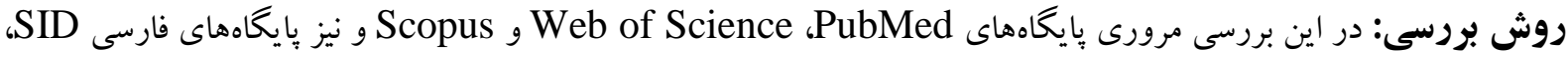
Magiran و Irandoc مقاله مرتبط در جستجوى اوليه، 9 مطالعه كوهورت واجد شرايط مورد ارزيابى قرار گرفتند. كيفيت مقـالات با استفاده از مقياس نيو كاسل اوتاوا ارزيابى گرديد. يافتهها: مطالعات مختلف از مقياسهاى مختلفى جهت بررسى تكامل عصبى كود كان استفاده كرده، به علاوه سن كودكان در

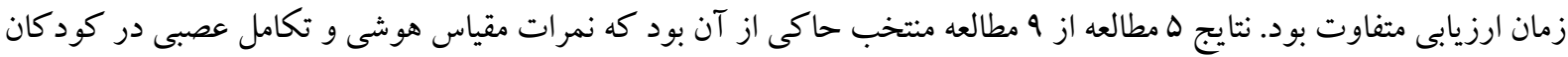
متولد شده از مادران مبتلا به هييوتيروئيدى تحت بالينى كمتر از كودكان متولد شده از مادران يوتيروئيد بود؛ ولى در \& مطالعه ديخر تفاوتى در نمر ات مقياس ها و ارزيابى تكامل عصبى شناختى كود كان مشاهده نغر دئريد.

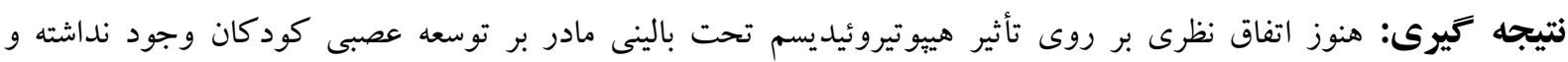

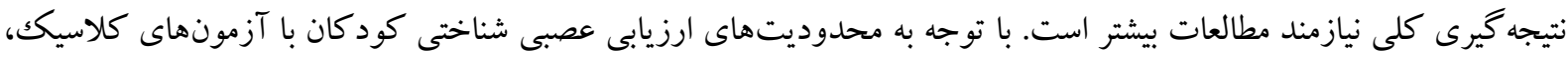

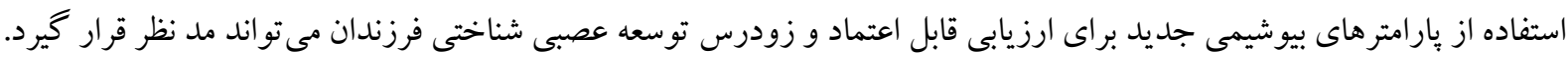
وازه هاى كليدى: هييوتيروئيدى تحت بالينى، باردارى، عصبى شناختى، تكامل، كودكان، مرور سيستماتيك.

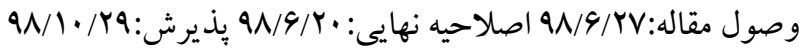


مصرف يد و سبك زندگى و نوع تغذيه و همجنين طرح هاى

مطالعاتى، بين f تا سا درصد متفاوت مىباشد (f (19). برخى مطالعات مشاهدهاى مبين افزايش يِامدهاى نامطلوب حاملكى شامل سقطجنين، مرگك جنين، زايمان زودرس، ديابت حاملكَى، فشارخون حاملكَى، اكلاميسى، جدا شدن زودرس جفتى، وزن كم هنگام تولد، آيگًار دقيقه ه كمتر از V در مادران مبتلا به هييو تيروئيدى تحت بالينى بوده اند V V

اكر جه بسيارى از مطالعات تأثير هيبوتيروئيدى تحت بالينى مادر را بر رشد، توسعه و سطح هوش كودكك مورد بررسى قرار داده اند؛ ولى نتايج مربوط به رشد عصبى روانشناختى فرزندان در مادر مبتلا، يكسان و كافى نبوده و كاهى متناقض

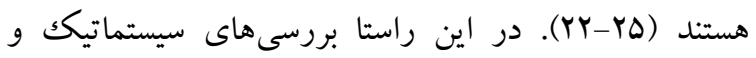
متا آناليز محدودى نيز وجود دارند. متا آناليز انجام شده توسط

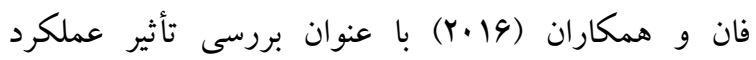
غيرطبيعى تيروئيد مادر بر روى تكامل روانى عصبى كود كان نشان دادند كه نمره هوش و نمره حركتى در كود كان گروه مادران مبتلا به هييوتيروئيدى تحت بالينى كمتر از گروه كنترل بودند (Yq). اين متآناليز بهطور اختصاصى روى هيبوتيروئيدى تحت بالينى انجام نشده بود و از 4 مطالعه ارزيابى شده در اين متآناليز تنها r مطالعه مربوط به مادران مبتلا به هييوتيروئيدى تحت بالينى بودند (YV) متآناليز ديخرى كه توسط ليو و همكارانش (1) (Y) انجام كرديد، گزارش شد كه ابتلا به هييو تيروئيدى تحت بالينى در دوران باردارى با افزايش خطر ابتلا به ييامدهاى نامطلوب از جمله تأخير در رشد فكرى و حركتى در كودكان همراه است؛ اما مقالات مورد ارزيابى در اين متآناليز نيز تنها روى ييامد تكامل عصبى كودكان نبوده و شامل بيامدهاى ديخر مانند وزن هنگام تولد، كم وزنى هنگام تولد و زايمان زودرس نيز بودند و از ها مقاله بررسى شده در اين متآناليز تنها F مطالعه در ارتباط با بيامد تكامل عصبى كودكان بودند(Y)). از اين رو براى نتيجه گيرى بهتر روى نتايج
هورمونهاى تيروئيد بلطور مستقيم و غيرمستقيم در فر آيندهاى مختلف متابوليك و سلولى در طول عمر داخل رحمى دخالت دارند. آنها براى رشد مناسب و تكامل عصبى جنين بسيار مهم هستند (1). هورمونهاى تيروئيد، فاكتور حياتى در تمامى مراحل تكوين مغز بوده و براى تكثير سلولهاى مغزى ضرورى هستند. اين هورمونها از طريق اثر بر سنتز يروتئين باعث افزايش رشد مى گردند. همجنين نقش مهمى در تمايز، توسعه و تكامل بافت دارند؛ بنابراين هورمونهاى تيروئيد نقش مهمى را در تكامل و بلوغ سيستم عصبى مركزى قبل و بعد از تولد بازى مى كنند (r, در طول باردارى، عمدتاً به دليل افزايش نياز هورمونى و انتقال هورمونهاى تيروئيد به جنين، تغييرات مهمى در تيروئيد اتفاق مىافتد (F) مطالعات نشان دادهاند كه اختلالات عملكرد تيروئيد و تغييرات در ذخيره هورمونهاى تيروئيد در طول تكامل سيستم عصبى منجر به تغييرات شديد و و غيرقابلبر گشت در ساختار و عملكرد مغز مى گردد (ه). بهطورى كه كمبود هورمون تيروئيد در طول تكامل سيستم عصبى مىتواند منجر به اختلال در بلوغ سلولهاى عصبى

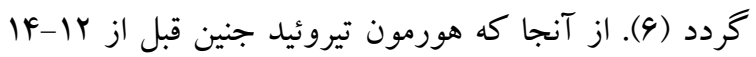
هفته باردارى به طور انحصارى از مادر تأمين مى گردد؛ بنابر اين اختلالات تيروئيد مادران در دوران باردارى با رشد و تكامل روان شناختى جنين ارتباط دارد (V). مطالعات متعدد نشان داده اند كه كم كارى و بر كارى آشكار تيروئيد هر دو عوامل خطرزاى شناخته شده براى ييامدهاى نامطلوب مختلف براى مادر و جنين مىباشند (^-Y |). بر اين اساس احتمال مىرود كه هيبوتيروئيدى تحت بالينى مادر نيز كه به صورت افزايش سطح هورمون محرك تيروئيد) (Thyroid stimulating hormone,TSH) در محدوده طبيعى تيروكسين (T4) و ترى يدو تريونين (T3) آزاد تعريف مىشود (سا)، اثرات نامطلوب بر رشد و توسعه جنين داشته باشد. هيبوتيروئيدى تحت بالينى شايع ترين اختلال عملكرد تيروئيد در دوران باردارى است كه شيوع آن، بر 
عاع تاثير هيبِوتيروئيدى تمت...

پايكاههاى مختلف پِ از حذف موارد تكرارى، به نرمافزار

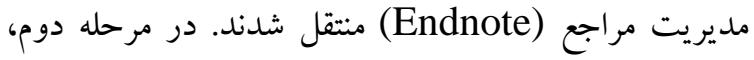

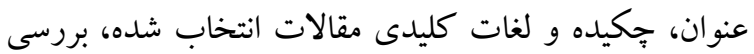
شدند و مقالاتى كه با موضوع اصلى يزوهش بى ارتباط بودند حذف گرديده و مقالات مرتبط انتخاب شدند. در مرحله سوم، با مطالعه متن كامل، مقالات نهايى براى مرور سيستماتيك انتخاب كرديدند.

جستجو براى يافتن مطالعه مرتبط در انواع مطالعات از قبيل

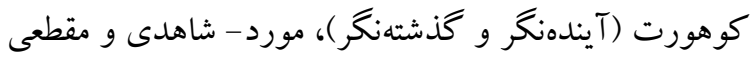

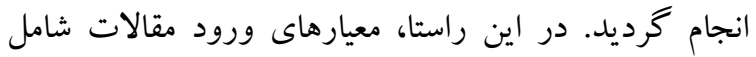
مقالات تحقيقى با موضوع مرتبط با بررسى تكامل كود كان متولد شده از مادران مبتلا به هييوتيروئيدى تحت بالينى بودند.

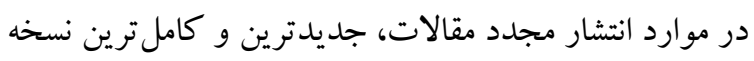

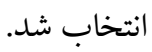
مقالات كنار كذاشته شده با توجه به هدف اصلى مطالعه حاضر، شامل مقالات مرورى يا دستورالعمل ها، مطالعات

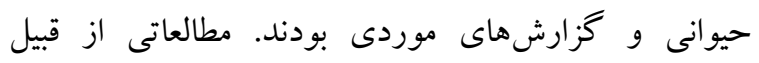

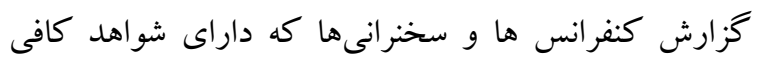

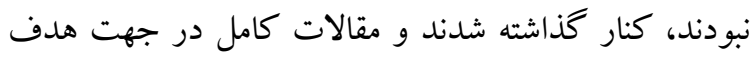
مطالعه انتخاب شدند. همجِنين مطالعاتى كه در در آنهار

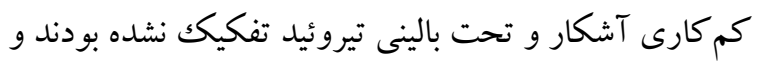
يا در آنها درمان با لووتيرو كسين در طول باردارى انجام شده بود و نيز مطالعاتى كه داراى داده هاى روشن نبودند، كنار

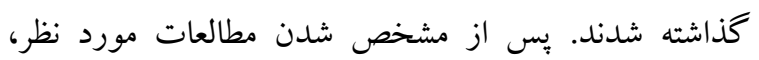

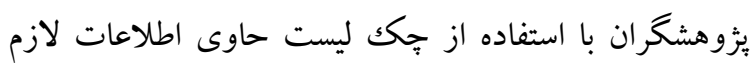
براى مطالعه، شامل نام نويسنده اول، عنو ان مقاله، سال جاب، محل انجام مطالعه، نوع مطالعه، نام مجله، تعداد نمونه كل، تعداد گروه (مورد و شاهد)، سن كود كان مورد مطالعه، ابزار مورد استفاده جهت ارزيابى وضعيت تكاملى كودكان، موارد لازم راثبت نمودند. در تمامى مراحل، انتخاب مقالات توسط دو يثزوهشگر بهطور جدا گانه انجام گرفت. مواردى كه مورد اختلاف بودند، توافق بر اساس بحث و اظهارنظر علمى

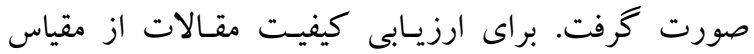

مطالعات مختلف، ضرورت انجام مطالعات مرورى از قبيل

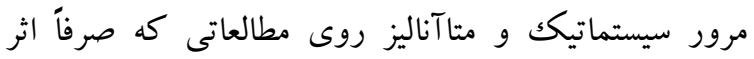
هييوتيروئيدى تحت بالينى مادر را بر تكامل عصبى كودكان بر بـى كرده باشند وجود دارد. بر اين اساس در حال حاضر، به دليل فقدان شو اهد معتبر، هيج توافقى نيز در مورد غربالكرى معمول هييوتيروئيدى تحت بالينى در زنان باردار، وجود ندارد و تصميم گيرى بر اين مسئله، نيازمند بررسىهاى بيشتر در زمينه مادران مبتلا به هييوتيروئيدى تحت بالينى و بيامدهاى آن بر مادر و كودكى به

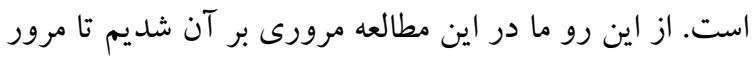

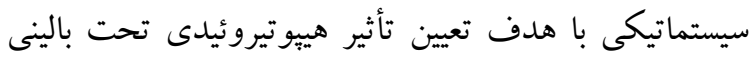
مادر بر تكامل عصبى شناختى كود كان انجام دهيم.

مواد و روش ها در اين مرور نظامند، جهت جماد وآورى اطلاعات از جستجوى سيستماتيك در پِايگاههاى PubMed (شامل Scopus ،Web of Science، Medline فارسى اطلاعات علمى جهاد دانشكاهى ( Scientific (Information database, SID علوم و فناورى اطلاعات ايران (Irandoc) و بانكك اطلاعات

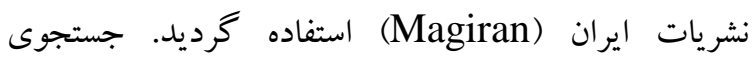
موضوعى بر اساس كلمات كليدى، بدون محدوديت زمانى تا تاني

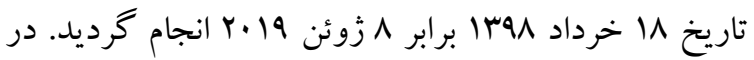

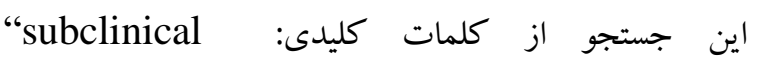

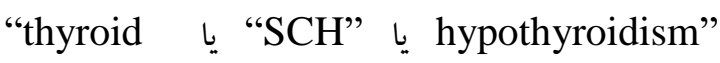
"maternal" يا يا "pregnancy" gdysfunction" ي "pregnancy outcome” يا ئ "fetal outcome”, يا “development" يا "neurodevelopmen” و "children” يا ئ "Intelligence"

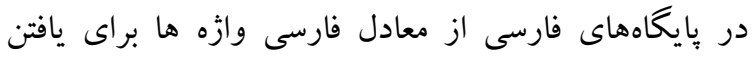

مطالعات مر تبط باهدف يزوهش استفاده شد (جدول () مطالعات در سه مرحله بررسى و انتخاب شدند: در مرحله نخست، مقالات استخراجشه بر اساس جستجوى در 
كه نمره تكامل عصبى كود كان متولد شده از مادران مبتلا به

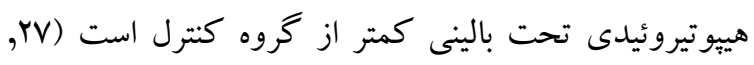

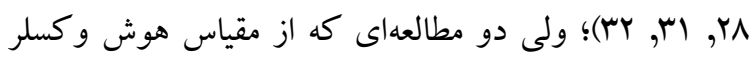

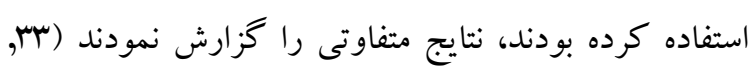
(YF

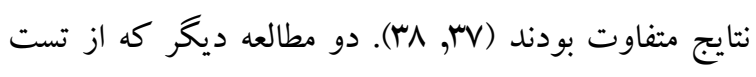

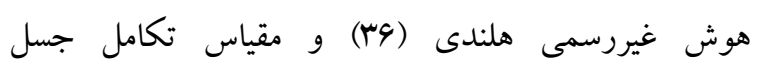

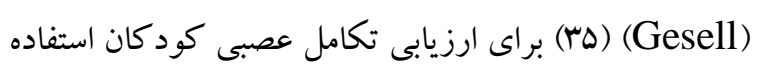

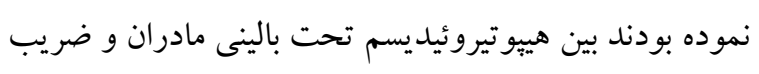

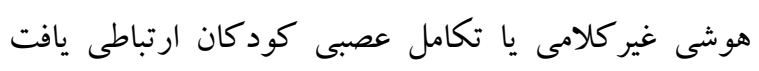
نشد. سن ارزيابى تكامل عصبى در مطالعات مورد بررسى، مختلف

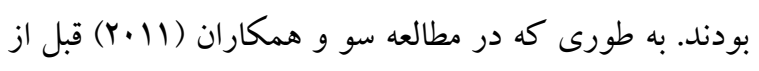

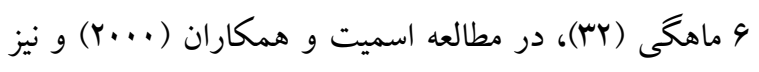

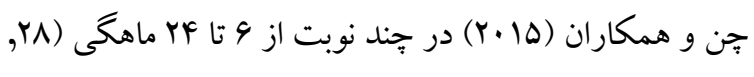

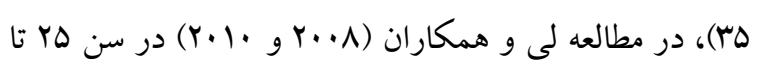

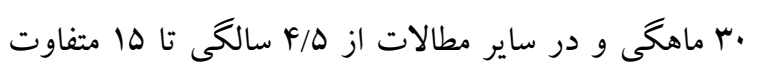

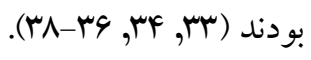
ارزيابى كيفيت مطالعات واجد شرايط: نتايج ارزيابى كيفيت مطالعات توسط مقياس نيو كاسل اوتاول

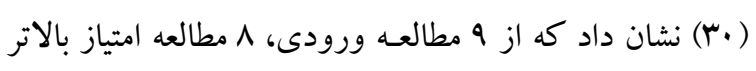

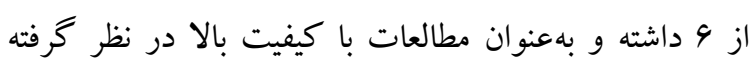

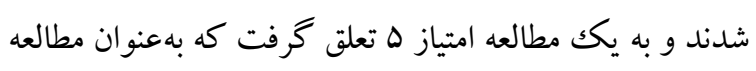
كيفيت متوسط در نظر گرفته شد. يافته هاى مطالعات مورد بررسى:

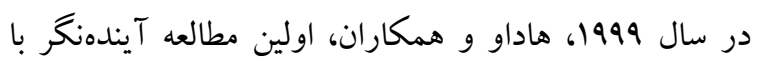

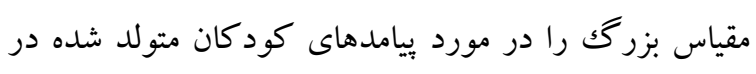

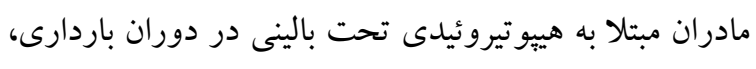

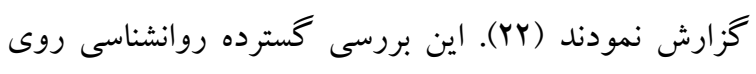

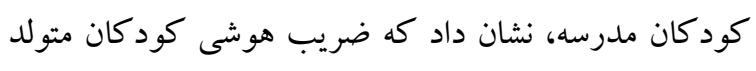

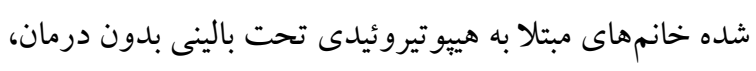

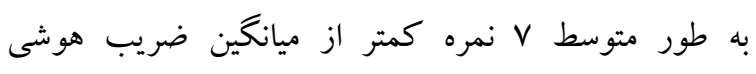

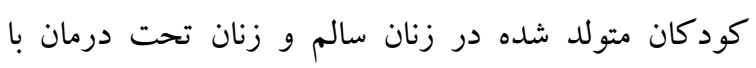

نيو كاسل اوتاوا (Newcastle-Ottawa) (•r) استفاده كرديد. در اين امتيازبندى كه براى ارزيل ابلى كيفيت

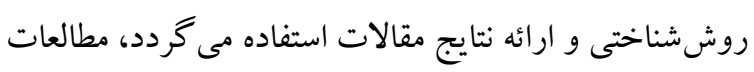

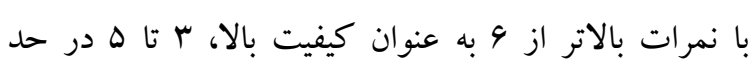

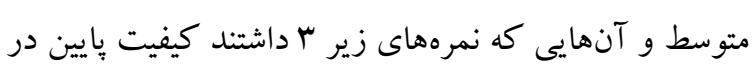
نظر كرفته شدند.

يافتهها شناسايى مطالعات واجد شرايط:

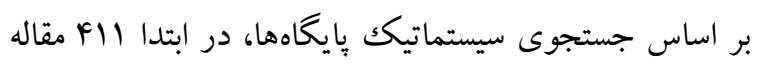

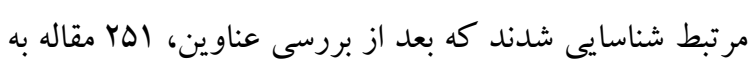

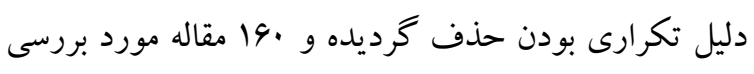

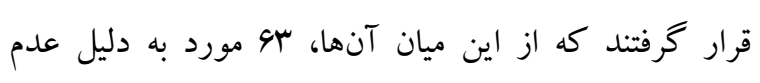

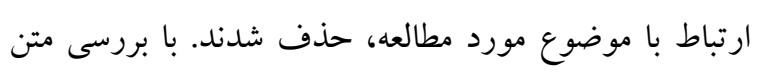

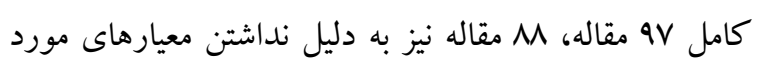

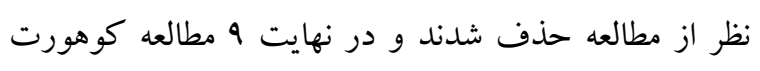

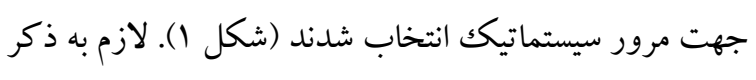

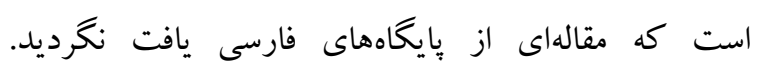

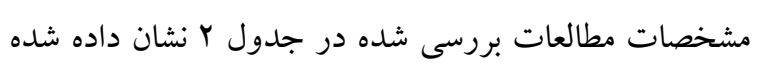

ارزيابى تكامل عصبى در كود كان: نتايج مرور سيستماتيك نشان داد كه مطالعات مختلف جهر بررسى تكامل عصبى كود كان، از مقياس هاى مختلفى استفاده

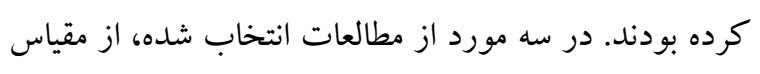

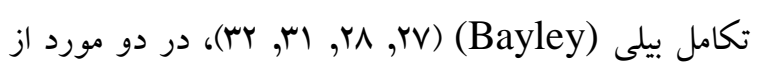

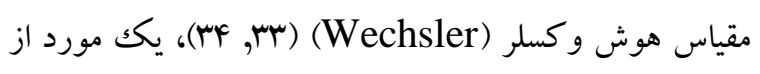

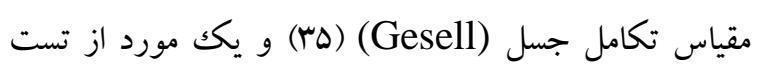
هوش غيررسمى هلندى اسنايدر اومن نايت وريل وريال (Snijders-Oomen Niet-verbale) گرديده بودند. در دو مطالعه نيز عملكرد مدرسه كودكان

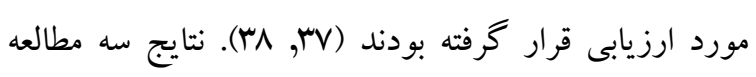

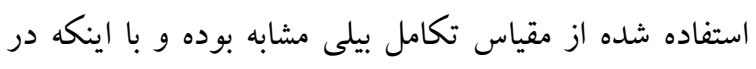
سنين متفاوتى انجام شده بودند هر سه بيانكر اين مطلب بودند 
4عا تاثير هيِيوتيروئيدى تمت...

مشكلات تحصيلى بيشترى در درس رياضيات نسبت به

دختران مادران يوتيروئيد بودند (YN). ارتباط بين هييو تيرو كسينمى در مادران و اختلالات رشدى نيز ابتدا توسط من و همكاران نشان داده شد (9\%)، با اين حال، ليو و همكاران تفاوت معنىدارى را در نمره هوشى هشت كودك متولد شده از مادران مبتلا به هيبوتيروئيدى مشاهده نكردند(F). با وجود اين، برخى مطالعات ديخر نتايج متفاوتى را در اين زمينه گزارش نمودند. از جمله مطالعه قربانى بهروز و همكارانش (11) سطح هوشى و عملكرد شناختى در كودكان متولد شده از مادران مبتلا به هيبوتيروئيدى تحت بالينى در باردارى، مشابه كود كان متولد شده از مادران يو تيروئيد بود (سM). همجنين در

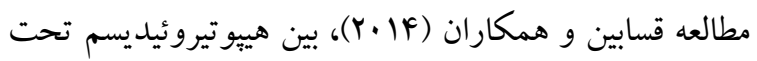
بالينى مادران و بهره هوشى غير كلامى كود كان ارتباطى يافت

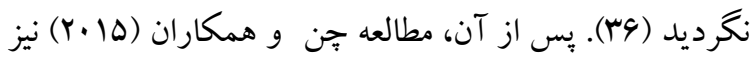
نشان داد كه نمرات آزمون تكامل عصبى در كودكان متولد شده از مادران مبتلا به هييوتيروئيدى تحت بالينى با كود كان متولد شده از مادران يوتيروئيد مشابه بوده و كمبود قابل توجهى در توسعه عصبى در كودكان تا سن YF ماهخى مشاهده نخرديد (ها). در سالهاى اخير، نلسون و همكارانش

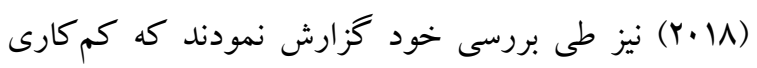
تحت بالينى تيروئيد مادر در اوايل باردارى ارتباط معنادارى بالقوهاى با عملكرد كود كان در مدرسه يا بيشرفت تحصيلى

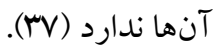

تيروكسين بود (YY). بعدها مطالعه اسميت و همكارانش نشان داد كه هييوتيروئيدى تحت بالينى مادر در نيمه (Y...) اول حاملكى با ميانگين بايينتر نمره تكامل ذهنى در نوزادان در طول سال اول زندگى همر اه است (YN). لى و همكارانش نيز نشان دادند كه اختلالات تحت بالينى تيروئيد مادر بين 19 تا · r هفته حاملكى ممكن است منجر به بروز اختلالات تكامل ذهنى و حركتى كود كان متولد شده گردد

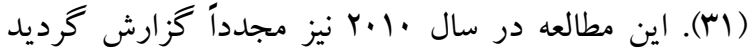
(YV) (YV). مطالعات ديخرى نيز در طى سالهاى مختلف به بررسى ستر اثر هييوتيروئيدى تحت بالينى مادر در دوران باردارى بر تكامل عصبى كود كان برداختند كه نتايج آنها نشان دهنده ميانگين هايينتر شاخص رشد ذهنى و تأخير در رشد مغز كودكان متولد شده از مادران مبتلا به هييوتيروئيدى تحت بالينى در دوران باردارى بود. به طورى كه در مطالعه سو و

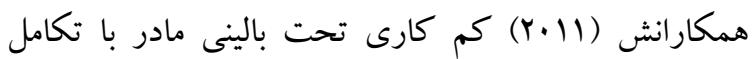
ضعيف بينايى و تأخير در تكامل عصبى در كودكان قبل از 4 ماهكى همراه بود (YM). همينطور مطالعه مورفى و همكاران (Y.10) نشان داد كه سطح هوشى و عملكرد شناختى در كودكان متولد شده از مادران مبتلا به هيبوتيروئيدى تحت بالينى در دوران باردارى كمتر از كودكان متولد شده از مادران با تيروئيد طبيعى بود (MF). مطالعه پاكيلا و همكاران (Y.10) نيز كه با در نظر كرفتن برخى فاكتورهاى مؤثر احتمالى تجزيهوتحليل گرديد، نشانگر اين بود كه دختران متولد شده از مادران مبتلا به هييوتيروئيدى تحت بالينى دجار

جدول ا. استراتزى و فرمولهاى جستجو در مطالعه در پايكاههاى اطلاعاتى مختلف مورد استفاده در مطالعه مرورى تأثير هييوتيروئيدى

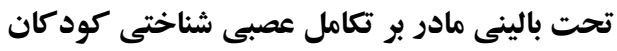
جزئيات جستجو

بإيخاه

PubMed ((("subclinical hypothyroidism"[Title/Abstract] OR SCH[Title/Abstract] OR "thyroid dysfunction"[Title/Abstract]) AND (Pregnancy[Title/Abstract] OR maternal[Title/Abstract])) AND ("fetal outcome"[Title/Abstract] OR "pregnancy outcome"[Title/Abstract] OR development[Title/Abstract] OR Intelligence[Title/Abstract])) AND (Offspring[Title/Abstract] OR children[Title/Abstract])

Scopus ( TITLE-ABS-KEY ("subclinical hypothyroidism" OR sch OR "thyroid dysfunction") AND TITLE-ABS-KEY (pregnancy OR maternal) AND TITLE-ABS-KEY ("fetal outcome" OR "pregnancy outcome" OR neurodevelopmen OR development OR intelligence) AND TITLE-ABS-KEY (offspring OR children)) AND DOCTYPE (ar) \# $1 \quad 16,080$ 
(TS=(subclinical hypothyroidism OR SCH OR thyroid dysfunction)) AND LANGUAGE: (English) AND DOCUMENT TYPES: (Article)

Indexes=SCI-EXPANDED, SSCI, CPCI-S, CPCI-SSH, ESCI Timespan=All years \# $2 \quad 378,973$

(TS=(Pregnancy OR maternal)) AND LANGUAGE: (English) AND DOCUMENT TYPES: (Article)

Indexes=SCI-EXPANDED, SSCI, CPCI-S, CPCI-SSH, ESCI Timespan=All years \# $3 \quad 2,533,684$

(TS=(fetal outcome OR pregnancy outcome OR neurodevelopmen OR development OR Intelligence)) AND LANGUAGE: (English) AND DOCUMENT TYPES: (Article) Indexes=SCI-EXPANDED, SSCI, CPCI-S, CPCI-SSH, ESCI Timespan=All years \# $4 \quad 1,045,995$

(TS=(Offspring OR children)) AND LANGUAGE: (English) AND DOCUMENT TYPES: (Article)

Indexes=SCI-EXPANDED, SSCI, CPCI-S, CPCI-SSH, ESCI Timespan=All years \# 5222

(\#1 AND \#2 AND \#3 AND \#4) AND LANGUAGE: (English) AND DOCUMENT TYPES: (Article)

Indexes=SCI-EXPANDED, SSCI, CPCI-S, CPCI-SSH, ESCI Timespan=All years

\begin{tabular}{|c|c|c|c|}
\hline \multirow[t]{5}{*}{$\begin{array}{l}\text { Web of } \\
\text { Science }\end{array}$} & $\# 1$ & 16,080 & $\begin{array}{l}\text { (TS=(subclinical hypothyroidism OR SCH OR thyroid } \\
\text { dysfunction)) AND LANGUAGE: (English) AND DOCUMENT } \\
\text { TYPES: (Article) } \\
\text { Indexes =SCI-EXPANDED, SSCI, CPCI-S, CPCI-SSH, ESCI } \\
\text { Timespan=All years }\end{array}$ \\
\hline & $\# 2$ & 378,973 & $\begin{array}{l}(\mathrm{TS}=(\text { Pregnancy OR } \\
\text { maternal)) AND LANGUAGE: (English) AND DOCUMENT } \\
\text { TYPES: (Article) } \\
\text { Indexes }=S C I-E X P A N D E D, S S C I, C P C I-S, C P C I-S S H, E S C I \\
\text { Timespan=All years }\end{array}$ \\
\hline & \multicolumn{3}{|c|}{$\begin{aligned} \text { \# } 3 \mathbf{2 , 5 3 3 , 6 8 4} \text { (TS=(fetal outcome OR pregnancy outcome OR neurodevelopmen OR } \\
\text { development OR } \\
\text { Intelligence)) AND LANGUAGE: (English) AND DOCUMENT } \\
\text { TYPES: (Article) } \\
\text { Indexes=SCI-EXPANDED, SSCI, CPCI-S, CPCI-SSH, ESCI } \\
\text { Timespan=All years }\end{aligned}$} \\
\hline & \multicolumn{3}{|c|}{$\begin{aligned} & \text { \# } 4 \text { 1,045,995 } \text { (TS }=(\text { Offspring OR } \\
& \text { children)) AND LANGUAGE: (English) AND DOCUMENT } \\
& \text { TYPES: (Article) } \\
& \text { Indexes=SCI-EXPANDED, SSCI, CPCI-S, CPCI-SSH, ESCI } \\
& \text { Timespan=All years }\end{aligned}$} \\
\hline & $\# 5$ & 222 & $\begin{array}{l}\text { (\#1 AND \#2 AND \#3 AND } \\
\text { \#4) AND LANGUAGE: (English) AND DOCUMENT TYPES: (Article) } \\
\text { Indexes=SCI-EXPANDED, SSCI, CPCI-S, CPCI-SSH, ESCI } \\
\text { Timespan=All years }\end{array}$ \\
\hline
\end{tabular}




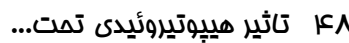

جدول r. مشخصات مطالعات بررسى شده در مطالعه مرورى تأثير هييوتيروئيدى تحت بالينى مادر بر تكامل عصبى شناختى كود كان

\begin{tabular}{|c|c|c|c|c|c|c|c|c|}
\hline نتايج & روش ارزيابى تكامل & سن بروسى & $\begin{array}{c}\text { معيار تعريف } \\
\text { SCH }\end{array}$ & $\begin{array}{l}\text { SCH/normal } \\
\text { (N) }\end{array}$ & مطالعه & مطالعل & انتشار & نويسندكان \\
\hline 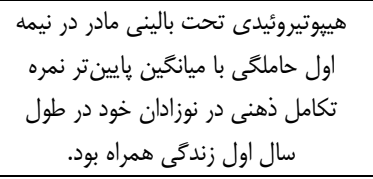 & مقياس تكامل ذهنى و & 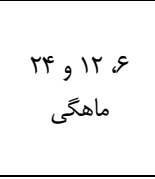 & $\begin{array}{c}\mathrm{TSH}>2 \mathrm{mlU} / \mathrm{L} \text {, } \\
\mathrm{FT} 4 \text { normal }\end{array}$ & 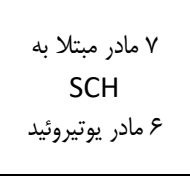 & كوهورت & هلند & $r \ldots$ & 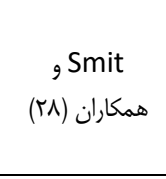 \\
\hline 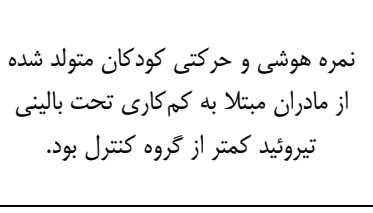 & Bayley مقياس تكامل & & $\begin{array}{l}\text { TSH }>4.21 \\
\text { mIU/l, normal } \\
\text { tT4 and fT4 } \\
\text { and TPOAb- }\end{array}$ & 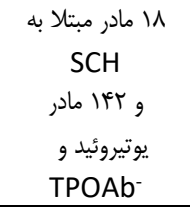 & كوهورت & קين & $\begin{array}{l}r \cdot r \\
r \cdot l \cdot\end{array}$ & 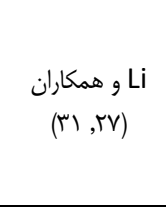 \\
\hline 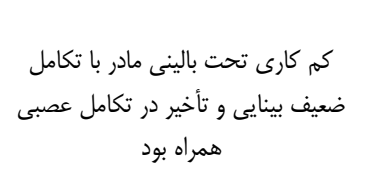 & Bayley مقياس تكامل & ق ماهل ازى 9 & $\begin{array}{l}\text { TSH >95th } \\
\text { percentile, } \\
\text { FT4 =5-95th }\end{array}$ & $\begin{array}{l}\text { أF مادر مبتلا به } \\
\text { SCH } \\
\text { يوتيروئيد مادر }\end{array}$ & كوهورت & קين & $r .11$ & $\begin{array}{l}\text { S و همكاران } \mathrm{Su} \\
\text { (זr) }\end{array}$ \\
\hline 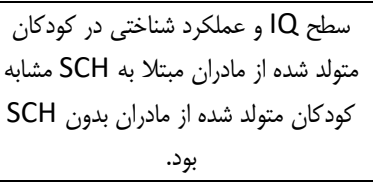 & $\begin{array}{l}\text { مقياس هوش } \\
\text { Wechsler }\end{array}$ & 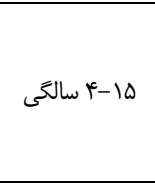 & $\mathrm{TSH}>3 \mathrm{mU} / \mathrm{L}$ & $\begin{array}{l}19 \\
19 \text { مادر مبتلاد به يوتيروئيد }\end{array}$ & كوهورت & ايران & $r+11$ & $\begin{array}{l}\text { Ghorbani } \\
\text { gehrooz } \\
\text { Bمكاران (rr) }\end{array}$ \\
\hline 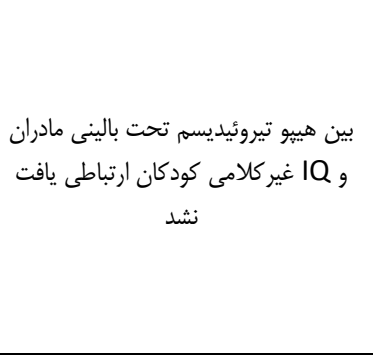 & $\begin{array}{c}\text { تست هوش غيررسمى } \\
\text { هلندى } \\
\text { (Snijders- } \\
\text { Oomen Niet- } \\
\text { verbale } \\
\text { intelligentie } \\
\text { test) }\end{array}$ & ع سالخى & $\begin{array}{c}\text { TSH }>2.5 \\
\text { mIU/L, FT4 } \\
\text { normal } \\
\text { TSH }>3 \text { mIU/L, } \\
\text { FT4 normal }\end{array}$ & 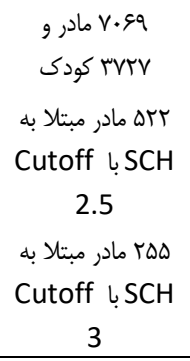 & كوهورت & هلند & $r \cdot 1 e^{e}$ & $\begin{array}{l}\text { Ghassabian } \\
\text { و هماران (ץع) }\end{array}$ \\
\hline 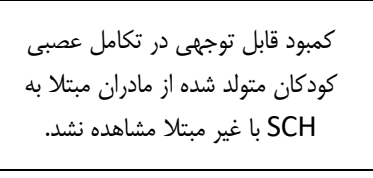 & $\begin{array}{c}\text { مقياس تكامل } \\
\text { Gesell }\end{array}$ & 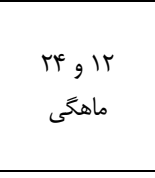 & $\begin{array}{l}\text { TSH }>97.5 \text { th } \\
\text { percentile, } \\
\text { FT4 normal }\end{array}$ & 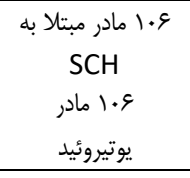 & كوهورت & קين & $r \cdot 10$ & $\begin{array}{l}\text { همكاران (rه Chen } \\
\text { همان }\end{array}$ \\
\hline 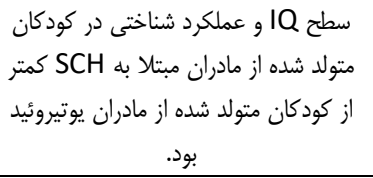 & $\begin{array}{l}\text { مقياس هوش } \\
\text { Wechsler }\end{array}$ & V-^ سالخى V-1 & $\begin{array}{l}\text { TSH }>98_{\text {th }} \\
\text { percentile, } \\
\text { FT4 normal }\end{array}$ & $\begin{array}{l}\text { س مادر مبتلا به } \\
\text { SCH } \\
\text { مادر يوتيروئيد }\end{array}$ & كوهورت & ايرلند ائد & $r \cdot 10$ & $\begin{array}{l}\text { و Marphy } \\
\text { وكاران (YYF) }\end{array}$ \\
\hline 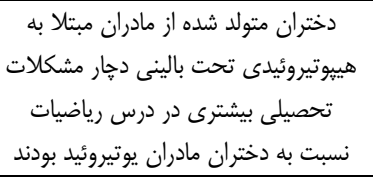 & عملكرد مدرسه كودكان & ^و 1 ا سالكَى & $\begin{array}{l}\mathrm{TSH}>3.1 \\
\mathrm{mIU} / \mathrm{L}, \mathrm{FT} 4 \\
\text { normal }\end{array}$ & 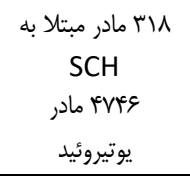 & كوهورت & 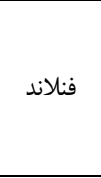 & $r \cdot 10$ & 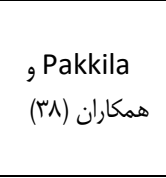 \\
\hline 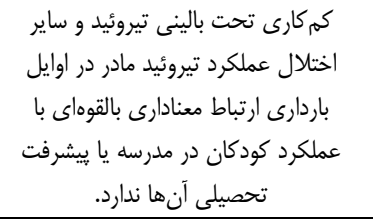 & هـ ارزيابى برنامه درسى سن & 1 & $\begin{array}{l}\text { TSH }>97.5_{\text {th }} \\
\text { FT4 normal } \\
\left(2.5_{\text {th }} \text { to }\right. \\
\left.97.5_{\text {th }}\right)\end{array}$ & $\begin{array}{c}\text { ع او مادر مبتلا به } \\
\text { SCH } \\
\text { يوتيروئيد مادر }\end{array}$ & كوهورت & انغلستان & $r \cdot 1 \Lambda$ & $\begin{array}{l}\text { و Nelson } \\
\text { همكاران(rv) }\end{array}$ \\
\hline
\end{tabular}

SCH, subclinical hypothyroidism; TSH, thyroid stimulating hormone; FT4, Free Thyroxine; TPOAb, thyroid peroxidase antibody; IQ, intelligence quotient. 


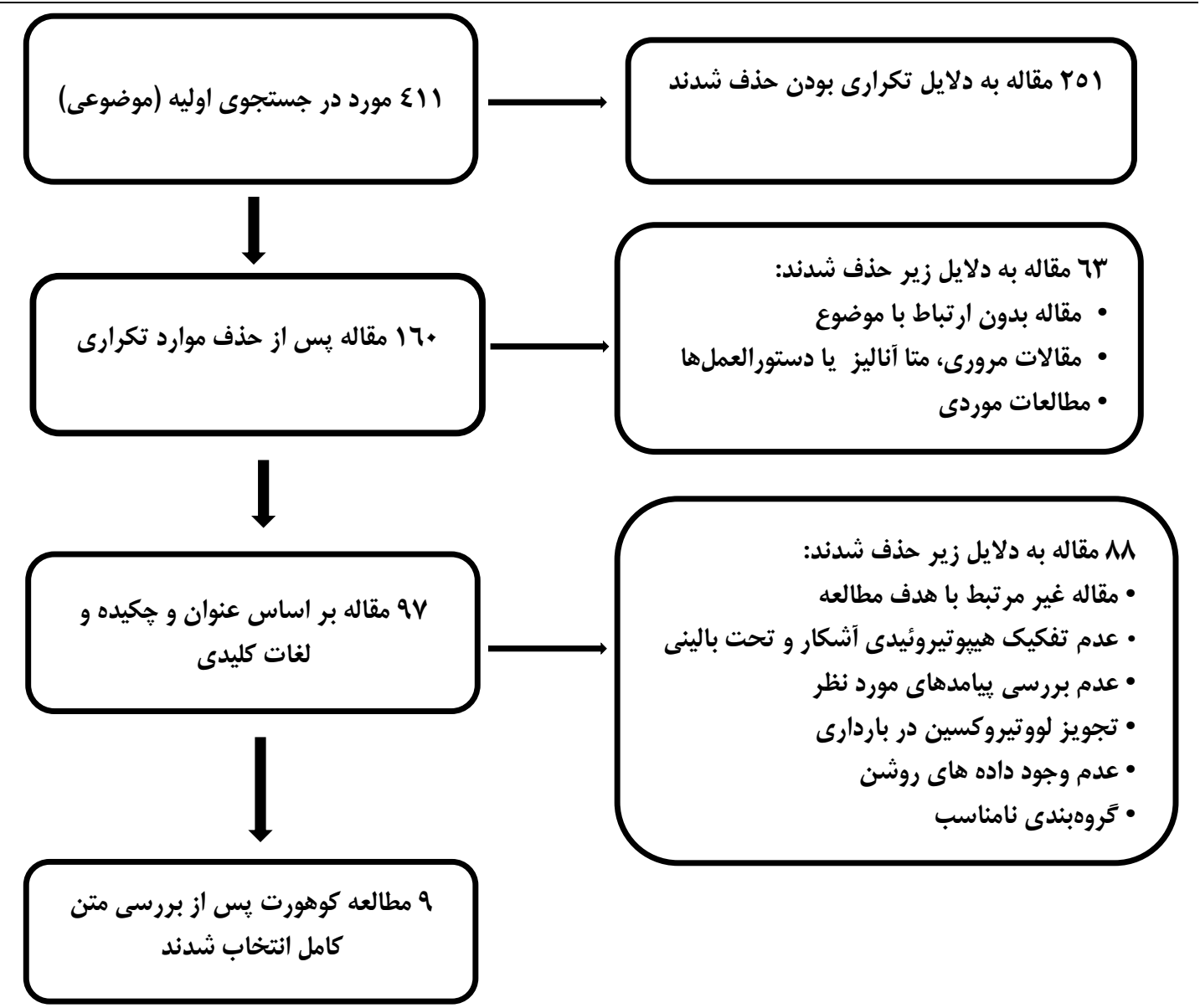

شكل ا. فلوجارت مطالعه

ايـن دوران مى تواند تكامل فيزيكى يا جسمى را تحت تأثير

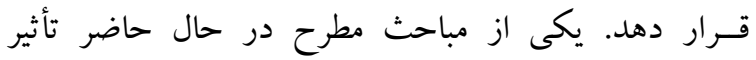
ارتباط بين هييوتيروئيديسم تحت بالينى مادر در دوران اختلالات تيروئيدى مادر بر تكامل عصبى شناختى فرزند

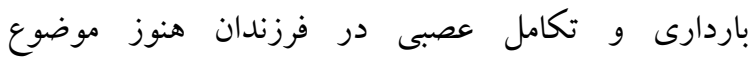

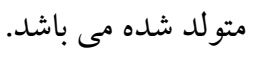
بحثبر انگيزى است كه ياسخ مشخصى براى آن وجود ندارد.

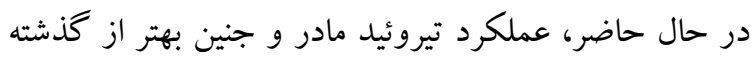

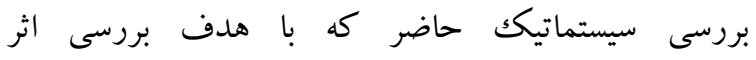
شناخته شده است و ييشرفت خوبى در مديريت هييوتيروئيدى

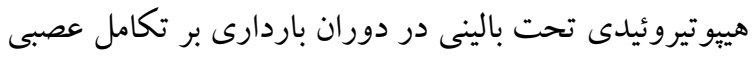

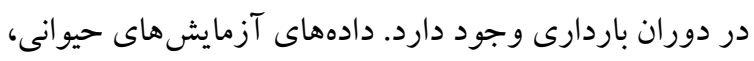

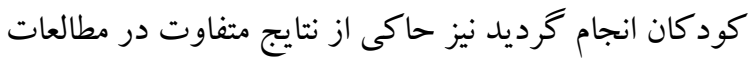
انتقال قابل توجه هورمون هاى تيروئيد از طريق جفت به جنين را نشان داده اند (Fr) و مكانيسم دقيقى كه با استفاده از آن

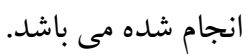
عملكرد غير طبيعى تيروئيد مادر مى تواند منجر به اختلالات رشد عصبى جنين شود، تنها تا حدى درك شده است (T) (Fr). هورمون تيروئيد از طريق اثر بر روى سنتز يروتئين باعث افزايش رشد مى شود. همجنين اين هورمون نقش مهمى در تمايز، توسعه و تكامل بافت دارد و براى تكثير سلول مغز طيف وسيعى از علل و عوامل جمعيت شناختى، از جمله بأند

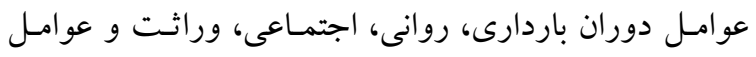

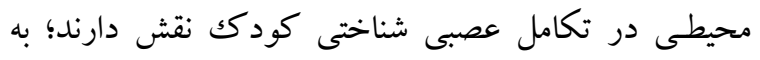

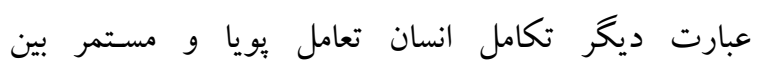

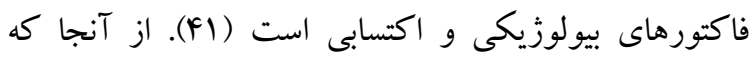

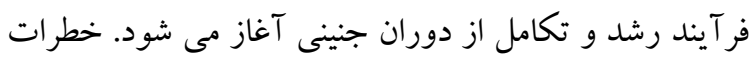


حاملكى مى گردد. از آنجايى كه هييوتيروئيدى در نوزادان نارس، يكك علت ثابت شده در اختلال تكامل عصبى در إنى دوران كودكى است، جنين تصور مى شود كه هييوتيروئيدى تحت بالينى در مادران ممكن است بر تكامل مغز جنين تأثير تصني

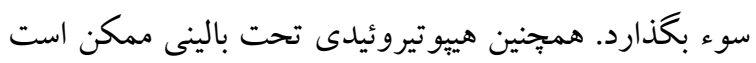
باعث ايجاد اختلال در تكامل جفتى رحمى و نارسايى جفتى

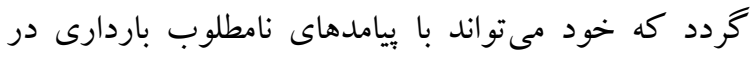
ارتباط باشد (1). فرضيه دوم بيان مى كند كه اختلال در سيستم جفتى رحمى در اوايل باردارى مىتواند به طور مستقيم منجر به اختلال در تستهاى عملكرد تيروئيد مادر و

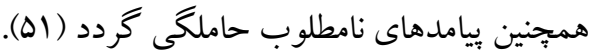
از مكانيسمهاى احتمالى مطرح شده ديخر ارتباط غير مستقيم تكامل عصبى كودكان متولد شده از مادران مبتلا به هييوتيروئيدى تحت بالينى در اثر بيامدهاى باردارى از قبيل

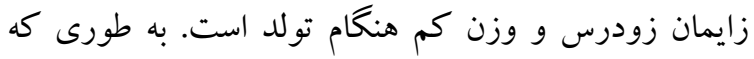

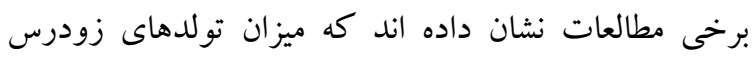

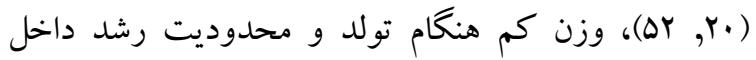

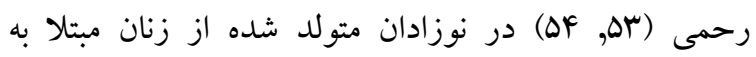
هيبوتيروئيدى تحت بالينى افزايش مى رئى يابد. از آنجا كه محدوديت رشد داخل رحمى و وزن كم هنگام تولد، عوامل

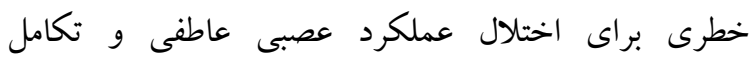

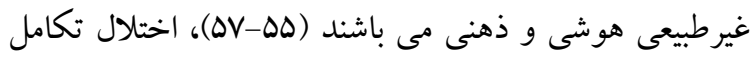
عصبى روانى در نوزادان متولد شده از مادران مبتلا به به به

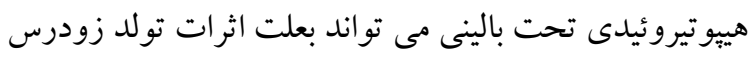
و ارتباط احتمالى بين محدوديت رشد داخل رحمى و وزن

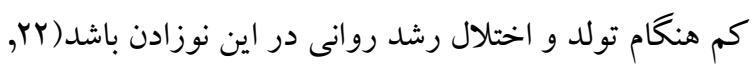

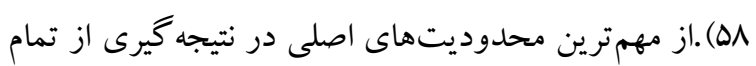
دادههاى منتشر شده براى ارزيابى اثر واقعى اختلال عملكرد تيروئيد در توسعهى عصبى جنين، مشكل بودن مقايسه نتايج

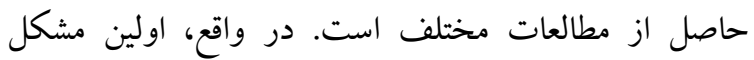
تعريف هييوتيروئيديسم تحت بالينى در طول حاملكى ست كه

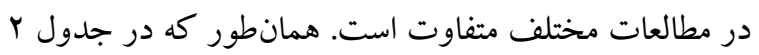

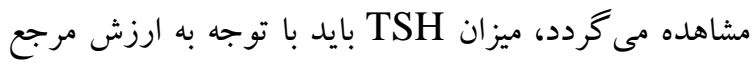

ضرورى است. به همين دليل عرضه مناسب هورمونهاى تهاى تيروئيد از ابتداى باردارى براى توسعه عصبى جنين ضرورى

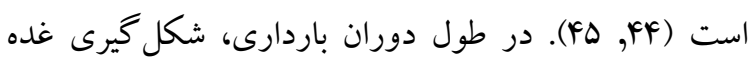

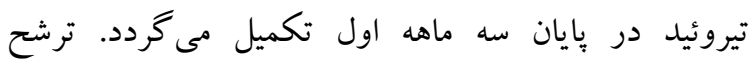

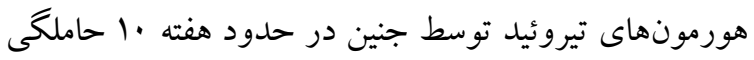
شروع شده و به ويزه در حدود 19 تا .r هفته باردارى فعال مى گردد (FV, F (FV). در مطالعات مختلف انجام شده، اهميت هورمونهاى مادرزادى تيروئيد در توسعه سيستم عصبى مركزى جنين به خوبى شناخته شده است. در برخى مطالعات تجربى، اثر مكانيسم هورمونهاى تيروئيد در توسعه مغز بررسى شده

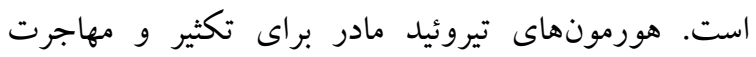

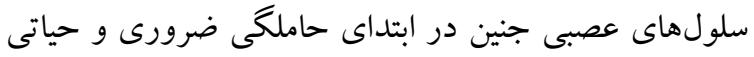

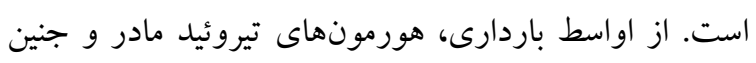

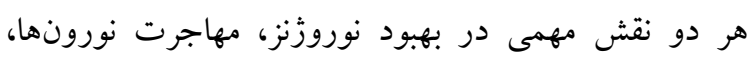

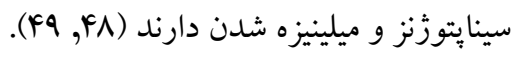
مطالعات متعدد نشان داده است كه كم كارى خفيف تيروئيد مادر با ييامدهاى نامطلوب عصبى شناختى در جنين مرتبط دئ داده است. در يكك مطالعه مورد شاهدى تاريخى بزركى، هاداو و

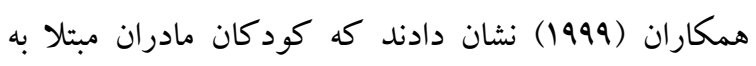

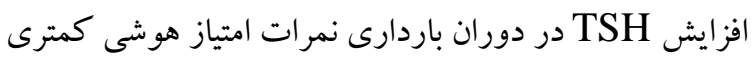

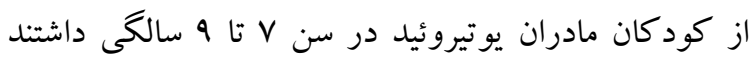

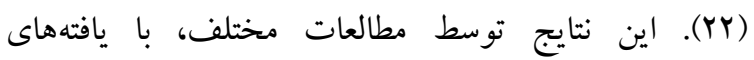
بهدست آمده در مورد اثر هييوتيروئيدى و هييوتيرو كسينمياى تئي مادر بر بهره هوشى و تكامل عصبى در كود كان مادران تائيد

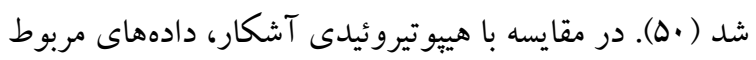
به تكامل عصبى روانشناختى فرزندان در مادر مبتلا به

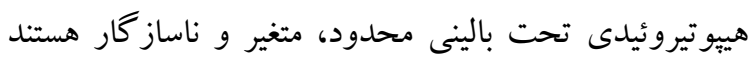

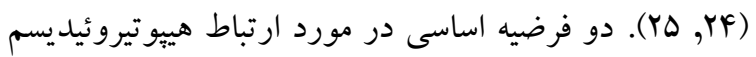
تحت بالينى مادر و بيامدهاى نامطلوب حاملكى در مطالعات

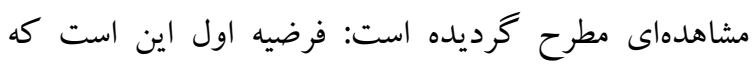
هيبوتيروئيدى تحت بالينى، به طور مستقيم، از طريق تغيير

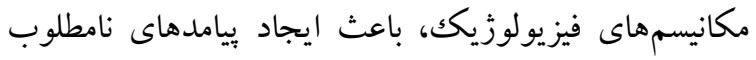


از طرفى، عوامل ديخرى مانند عوامل محيطى، ميززان

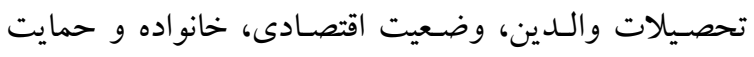

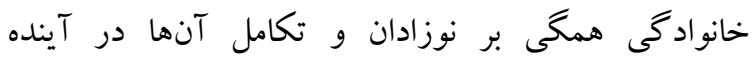

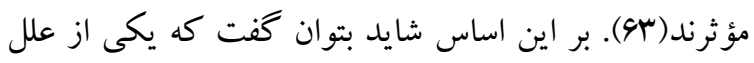

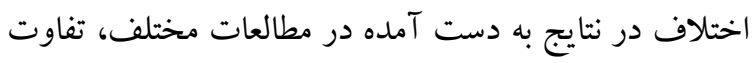
آنها در جمعيتهاى مورد بررسى و وضعيت هاى گوناكون

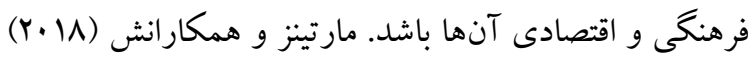

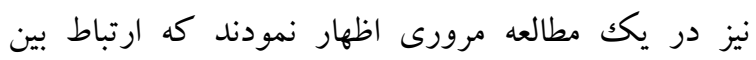

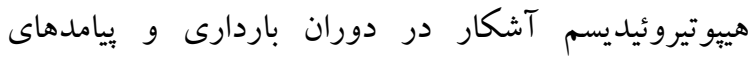
نامطلوب باردارى و يرى ناتال به خوبى شناخته شدهاند.

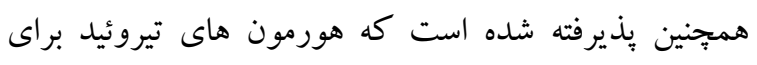

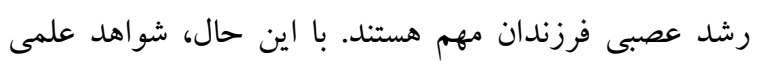
كافى در مورد تأثير هييوتيروئيدى تحت بالينى و درمان آن درن طول سه ماهه اول باردارى بر توسعه عصبى كودكان وجود دود دئي

$$
\text { ندارد (DQ). }
$$

دو مطالعه متآناليز فان و همكاران (19) (Y) و ليو و همكارانش

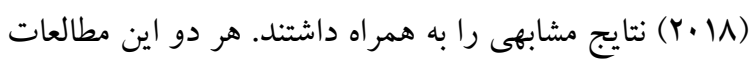
بيانكر يايين بودن نمره هوشى و تكامل عصبى كود كان متولد

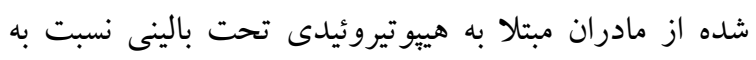

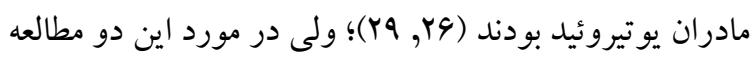
نيز مواردى جاى بحث دارند. بررسى سيستماتيك و متآ آناليز

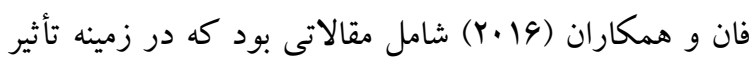
عملكرد غيرطبيعى تيروئيد مادر بر روى تكامل روانى عصبى منى

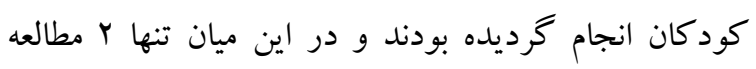

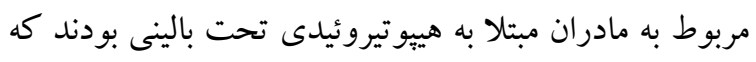

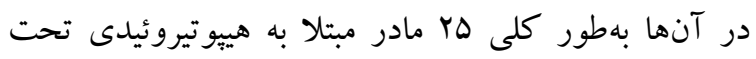

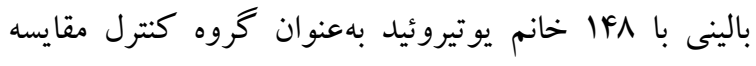

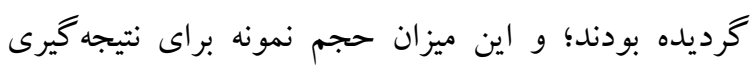

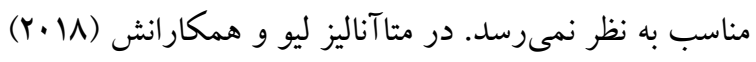

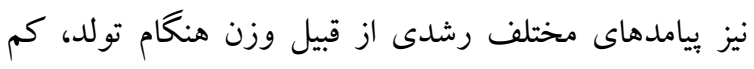

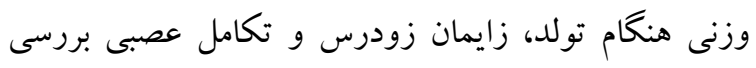

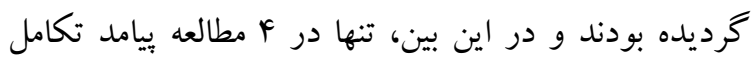

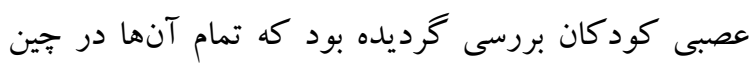

متناسب با هر جمعيت و براى هر روش فنى ارزيابى شود، همانطور كه در مطالعات بررسى شده مشاهده مى كردد معيار

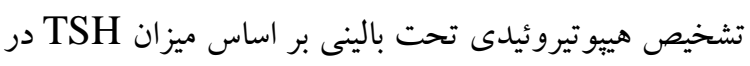
مطالعات مختلف يكسان نبوده و اين مسئله نيز باعث ايجاد محدوديت در مقايسه نتايج مطالعات با هم مى خردد.

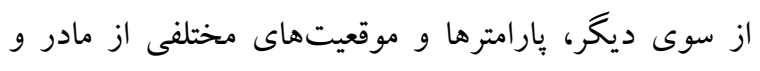

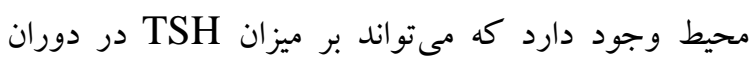

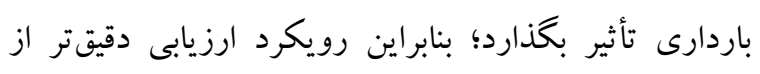

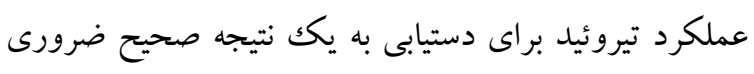

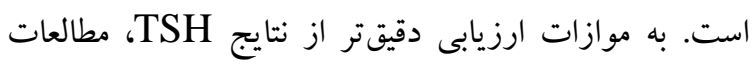
مبتنى بر جمعيت در مورد مقادير مرجع TSH كه در آن

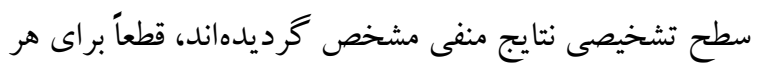

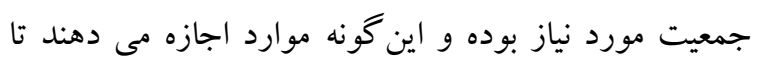
نتيجه گيرى مطلوبتر و صحيحترى از مطالعات داشته باشيم و

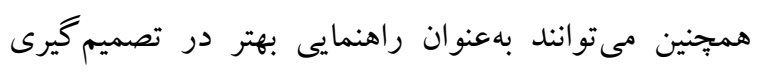

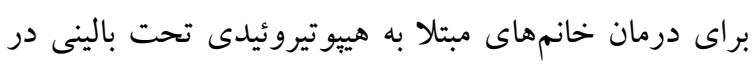
طول باردارى مورد استفاده قرار گيرند (هوه). از طرف ديخر ارزيابى تكامل عصبى شناختى كودكان در درد مطالعات مختلف در سنين مختلفى و با آزمونهاى تكامل عصبى متفاوتى انجام گرديده است. بسيارى از آزمونهاى

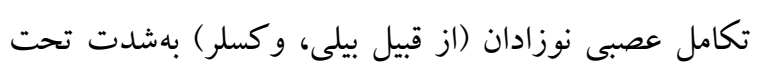
تأثير متغيرهاى اجتماعى-فرهنگى، اقتصادى و آموزشى قرار

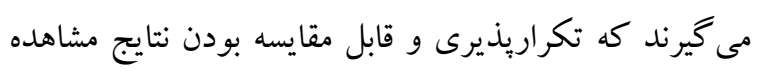

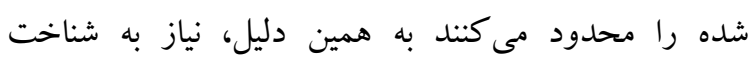
نشانكرهاى مرتبط با توسعهى عصبى كه امكان ارزيابى عينى

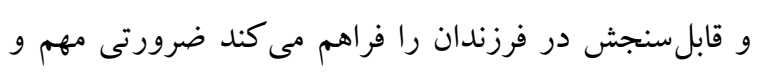
اساسى است (ه9). در حال حاضر بيوماركرهاى ويزه تكثير و مهاجرتهاى الهان

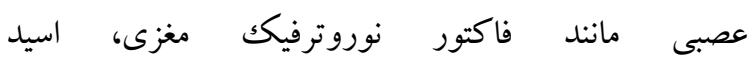
لسيوفسفاتيديك، فاكتور نوروترفيكك رشد مشخص شده اند فئن

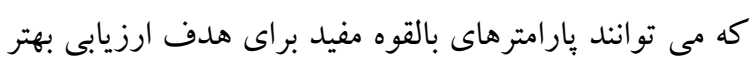
توسعلى عصبى نوزادان باشند ( •9-9Y). 
كودكان با آزمونهاى كلاسيك داراى قابليت تكراريذيرى محدود است، استفاده از يارامترهاى بيوشيمى جديد نيز براى

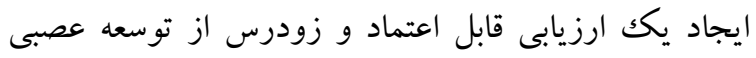
شناختى در فرزندان متولد شده مناسب به نظر مىرسد؛ كه البته اين موضوع زمينه بسيار جالب مطالعه را از نظر بزشكى و آزمايشگاهى بالينى باز مى كند و مطالعات بيشترى را مى طلبد.

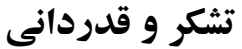

اين مقاله حاصل بررسى مرورى مقالات متعدد در زمينه تأثير

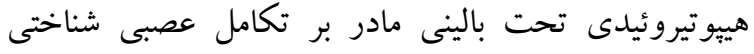
كودكان مى باشد. بدينوسيله از كليه محققينى كه در اين زمينه در جهت ارتقاى دانش و در نتيجه سلامت مادر و كودكك قدم برداشته اند تشكر و قدردانى مى كرددد. هيج

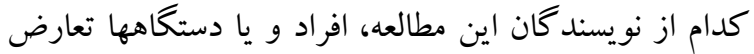
منافعى براى انتشار اين مقاله ندارند.

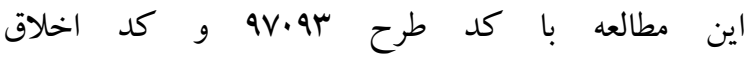
IR.SBMU.ENDOCRINE.REC.1397.126 يزوهشكده غدد درون ريز دانشگاه علوم يزشكى شهيد بهشتى مورد تصويب قرار گرفت.
انجام شده بودند و ما در جستجوى خود نتوانستيم به دو مقاله آن دست بيدا كنيم (4), 90). با توجه به تأثير متغيرهاى اجتماعى-فرهنكى بر تكامل عصبى كود كان به نظر مىرسد

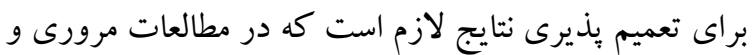

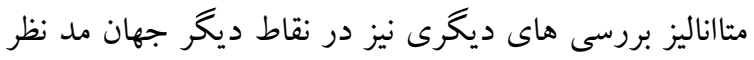
قرار گيرند. نقطه قوت اين مطالعه، بررسى دقيق مطالعات بر اساس گروهو بندى مورد نظر و حذف مطالعاتى بود كه در آن ها از لووتيروكسين استفاده كرده بودند. همجنين از آنجا كه تمام مطالعات انتخاب شده در اين مرور سيتماتيك از نوع كوهورت بودند و اين مطالعات نقطه عطف بررسى هاى تحليلى و مناسب براى تعيين روابط عليتى هستند، دقت و نتايج قابل اعتمادترى در بر دارند كه در در اين مرور سيستماتيك به آن ها برداخته شد. مرور سيستماتيك حاضر با محدوديت هايى نيز مواجه بوده

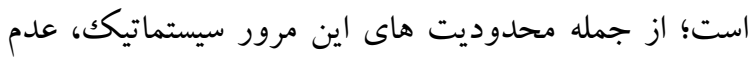

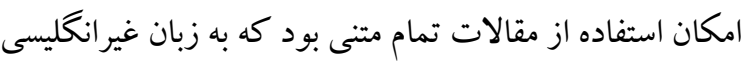
در دسترس بوده اند. و نيز با وجود جستجوى گسترده مقالات، امكان دارد برخى مطالعات انجام شده كه قابليت ورود به مرور سيستماتيك را دارند، يافت نغخرديده و واتهات

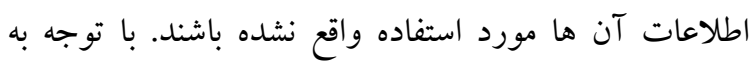
محدود بودن مطالعات كوهورت و متآناليز در مورد تأثير هييوتيروئيد مادر بر تكامل عصبى كودكان متولد شده، مونا

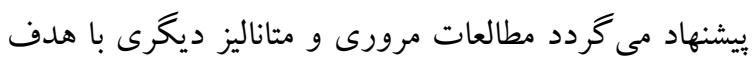
مذكور انجام گردد.

نتيجه كيرى اين مرور سيستماتيك نشان داد كه تأثير تغييرات در عملكرد تيروئيد مادر در محدودههايى كه به عنوان هييوتيروئيديسم تحت بالينى شناخته مى شود، بر روى توسعه عصبى كود كان متولد شده هنوز مشخص نيست؛ و اين مسئله لزوم توجه بيشتر

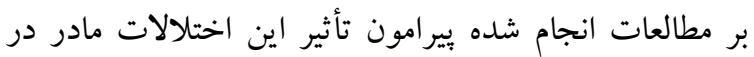
باردارى بر تكامل عصبى كودكان متولد شده را مطرح

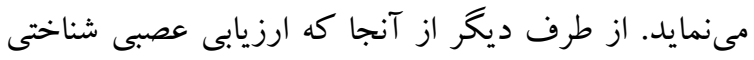


1.Forhead AJ, Fowden AL. Thyroid hormones in fetal growth and prepartum maturation. J Endocrinol. 2014;221(3):87-103.

2.Ahmed OM, El-Gareib A, El-Bakry A, El-Tawab SA, Ahmed R. Thyroid hormones states and brain development interactions. Int J Dev Neurosci. 2008;26(2):147-209.

3.Zoeller R, Rovet J. Timing of thyroid hormone action in the developing brain: clinical observations and experimental findings. J Neuroendocrinol. 2004;16(10):809-18.

4.Moleti M, Trimarchi F, Vermiglio F. Thyroid physiology in pregnancy. Endocr Pract. 2014;20(6):589-96.

5.Borhani Haghighi M, Pasand Mojdeh H, Alipour F. The Role of Thyroid Hormones in the Central Nervous System. Shefaye Khatam. 2017;5(4): 87-97.

6.Bianco AC. Metabolic Effects of Thyroid Hormones-Beyond Traditional Prospects. Thyroid. 2008;18(2):99-100.

7.De Escobar GM, Obregón MJ, Del Rey FE. Role of thyroid hormone during early brain development. Eur J Endocrinol. 2004;151:25-37.

8.Krassas G, Poppe K, Glinoer D. Thyroid function and human reproductive health. Endocr Rev. 2010;31(5):702-55.

9.R Vameghi MD M. Motor developmental delay in 7500 Iranian infants: Prevalence and risk factors. Iran J Child Neurol. 2009;3(3):43-50.

10.Nazarpour S, Ramezani Tehrani F, Simbar M, Azizi F. Pregnancy outcomes in pregnant women with hypothyroidism (a review article). Iran $\mathbf{J}$ Obstet Gynecol Infertil. 2014;17(126):17-26.

11.Nazarpour S, Ramezani Tehrani F, Simbar M, Azizi F. Thyroid autoantibodies and the effect on pregnancy outcomes. J Obstet Gynaecol. 2016;36(1):3-9.

12.Nazarpour S, Tehrani FR, Simbar M, Azizi F. Thyroid dysfunction and pregnancy outcomes. Iran J Reprod Med. 2015;13(7):387.

13.Maraka S, Ospina NMS, O'Keeffe DT, Espinosa De Ycaza AE, Gionfriddo MR, Erwin PJ, et al. Subclinical hypothyroidism in pregnancy: a systematic review and meta-analysis. Thyroid. 2016;26(4):580-90.

14.Al Shanqeeti SA, Alkhudairy YN, Alabdulwahed AA, Ahmed AE, Al-Adham MS, Mahmood NM. Prevalence of subclinical hypothyroidism in pregnancy in Saudi Arabia. Saudi Med J. 2018;39(3):254.

15.Garmendia Madariaga A, Santos Palacios S, Guillén-Grima F, Galofré JC. The incidence and prevalence of thyroid dysfunction in Europe: a meta-analysis. J Clin Endocrinol Metab. 2014;99(3):923-31.

16.Nazarpour S, Tehrani FR, Amiri M, Yarandi RB, Azizi F. Levothyroxine treatment and pregnancy outcomes in women with subclinical hypothyroidism: a systematic review and meta-analysis. Arch Gynecol Obstet. 2019:1-15.

17.Negro R, Stagnaro-Green A. Diagnosis and management of subclinical hypothyroidism in pregnancy. Bmj. 2014;349:4929.

18. Maraka S, Mwangi R, McCoy RG, Yao X, Sangaralingham LR, Ospina NMS, et al. Thyroid hormone treatment among pregnant women with subclinical hypothyroidism: US national assessment. Br Med J. 2017;356:i6865.

19.Maraka S, Singh Ospina NM, O'Keeffe DT, Rodriguez-Gutierrez R, Espinosa De Ycaza AE, Wi C-I, et al. Effects of levothyroxine therapy on pregnancy outcomes in women with subclinical hypothyroidism. Thyroid. 2016;26(7):980-6. 
عاه ماثير هيبِوتيروائيدى تصت...

20.Nazarpour S, Ramezani Tehrani F, Simbar M, Tohidi M, Minooee S, Rahmati M, et al. Effects of levothyroxine on pregnant women with subclinical hypothyroidism, negative for thyroid peroxidase antibodies. J Clin Endocrinol Metab. 2017;103(3):926-35.

21.Nazarpour S, Tehrani FR, Simbar M, Tohidi M, Majd HA, Azizi F. Effects of levothyroxine treatment on pregnancy outcomes in pregnant women with autoimmune thyroid disease. Eur J Endocrinol. 2017;176(2):253-65.

22.Haddow JE, Palomaki GE, Allan WC, Williams JR, Knight GJ, Gagnon J, et al. Maternal thyroid deficiency during pregnancy and subsequent neuropsychological development of the child. N Engl J Med. 1999;341(8):549-55.

23.Korevaar TI, Muetzel R, Medici M, Chaker L, Jaddoe VW, de Rijke YB, et al. Association of maternal thyroid function during early pregnancy with offspring IQ and brain morphology in childhood: a population-based prospective cohort study. Lancet Diabetes Endocrinol. 2016;4(1):35-43.

24.Man EB, Brown J, Serunian S. Maternal hypothyroxinemia: psychoneurological deficits of progeny. Ann Clin Lab Sci. 1991;21(4):227-39.

25.Man EB, Jones WS, Holden RH, Mellits ED. Thyroid function in human pregnancy: VIII. Retardation of progeny aged 7 years; relationships to maternal age and maternal thyroid function. Am J Obstet Gynecol. 1971;111(7):905-16.

26.Fan $\mathrm{X}, \mathrm{Wu} \mathrm{L}$. The impact of thyroid abnormalities during pregnancy on subsequent neuropsychological development of the offspring: a meta-analysis. J Matern Fetal Neonatal Med. 2016;29(24):3971-6.

27.Li Y, Shan Z, Teng W, Yu X, Li Y, Fan C, et al. Abnormalities of maternal thyroid function during pregnancy affect neuropsychological development of their children at 25-30 months. Clin Endocrinol. 2010;72(6):825-9.

28.Smit B, Kok J, Vulsma T, Briet J, Boer K, Wiersinga W. Neurologic development of the newborn and young child in relation to maternal thyroid function. Acta Paediatr. 2000;89(3):291-5.

29.Liu Y, Chen H, Jing C, Li F. The association between maternal subclinical hypothyroidism and growth, development, and childhood intelligence: A meta-analysis. J Clin Res Pediatr Endocrinol. 2018;10(2):153.

30.Stang A. Critical evaluation of the Newcastle-Ottawa scale for the assessment of the quality of nonrandomized studies in meta-analyses. Eur J Epidemiol. 2010;25(9):603-5.

31.Li Y, Teng W, Shan Z, Zhang L, Zhao Y, Yu X, et al. Effect of maternal subclinical thyroid abnormalities on offspring's intellectual development. Chinese Journal of Endocrinology and Metabolism. 2008;24(6):601-4.

32.Su P-Y, Huang K, Hao J-H, Xu Y-Q, Yan S-Q, Li T, et al. Maternal thyroid function in the first twenty weeks of pregnancy and subsequent fetal and infant development: a prospective population-based cohort study in China. J Clin Endocrinol Metab. 2011;96(10):3234-41.

33.Behrooz HG, Tohidi M, Mehrabi Y, Behrooz EG, Tehranidoost M, Azizi F. Subclinical hypothyroidism in pregnancy: intellectual development of offspring. Thyroid. 2011;21(10):1143-7.

34.Murphy NC, Diviney MM, Donnelly JC, Cooley SM, Kirkham CH, Foran AM, et al. The effect of maternal subclinical hypothyroidism on IQ in 7-to 8-year-old children: A casecontrol review. Aust N Z J Obstet Gynaecol. 2015;55(5):459-63.

35.Chen L, Chen Q, Jin G, Si G, Zhang Q, Ye E, et al. Effect of gestational subclinical hypothyroidism on early neurodevelopment of offspring. J Perinatol. 2015;35(9):678. 
36.Ghassabian A, El Marroun H, Peeters RP, Jaddoe VW, Hofman A, Verhulst FC, et al. Downstream effects of maternal hypothyroxinemia in early pregnancy: nonverbal IQ and brain morphology in school-age children. J Clin Endocrinol Metab. 2014;99(7):2383-90.

37.Nelson SM, Haig C, McConnachie A, Sattar N, Ring SM, Smith GD, et al. Maternal thyroid function and child educational attainment: prospective cohort study. bmj. 2018;360:k452.

38.Päkkilä F, Männistö T, Hartikainen A-L, Ruokonen A, Surcel H-M, Bloigu A, et al. Maternal and child's thyroid function and child's intellect and scholastic performance. Thyroid. 2015;25(12):1363-74.

39.Man EB, Serunian SA. Thyroid function in human pregnancy: IX. Development or retardation of 7-year-old progeny of hypothyroxinemic women. Am J Obstet Gynecol. 1976;125(7):949-57.

40.Liu H, Momotani N, Noh JY, Ishikawa N, Takebe K, Ito K. Maternal hypothyroidism during early pregnancy and intellectual development of the progeny. Arch Intern Med. 1994;154(7):785-92.

41.de Moura DR, Costa JC, Santos IS, Barros AJD, Matijasevich A, Halpern R, et al. Risk factors for suspected developmental delay at age 2 years in a Brazilian birth cohort. Paediatr Perinat Epidemiol. 2010;24(3):211-21.

42.Porterfield SP, Hendrich CE. The role of thyroid hormones in prenatal and neonatal neurological development — current perspectives. Endocr Rev. 1993;14(1):94-106.

43.Schwartz HL, Ross ME, Oppenheimer JH. Lack of effect of thyroid hormone on late fetal rat brain development. Endocrinol. 1997;138(8):3119-24.

44.Henrichs J, Ghassabian A, Peeters RP, Tiemeier H. Maternal hypothyroxinemia and effects on cognitive functioning in childhood: how and why? Clin Endocrinol. 2013;79(2):152-62.

45.Patel J, Landers $\mathrm{K}, \mathrm{Li} \mathrm{H}$, Mortimer $\mathrm{R}$, Richard $\mathrm{K}$. Thyroid hormones and fetal neurological development. J Endocrinol. 2011;209(1):1-8.

46.Burrow GN, Fisher DA, Larsen PR. Maternal and fetal thyroid function. N Engl J Med. 1994;331(16):1072-8.

47.Williams G. Neurodevelopmental and neurophysiological actions of thyroid hormone. J Neuroendocrinol. 2008;20(6):784-94.

48. Haddow JE, McClain MR, Lambert-Messerlian G, Palomaki GE, Canick JA, ClearyGoldman J, et al. Variability in thyroid-stimulating hormone suppression by human chronic gonadotropin during early pregnancy. J Clin Endocrinol Metab. 2008;93(9):3341-7.

49.Mohan V, Sinha RA, Pathak A, Rastogi L, Kumar P, Pal A, et al. Maternal thyroid hormone deficiency affects the fetal neocorticogenesis by reducing the proliferating pool, rate of neurogenesis and indirect neurogenesis. Exp Neurol. 2012;237(2):477-88.

50.Pop VJ, Kuijpens JL, van Baar AL, Verkerk G, van Son MM, de Vijlder JJ, et al. Low maternal free thyroxine concentrations during early pregnancy are associated with impaired psychomotor development in infancy. Clin Endocrinol. 1999;50(2):149-55.

51. Yamamoto JM, Benham JL, Nerenberg KA, Donovan LE. Impact of levothyroxine therapy on obstetric, neonatal and childhood outcomes in women with subclinical hypothyroidism diagnosed in pregnancy: a systematic review and meta-analysis of randomised controlled trials. BMJ open. 2018;8(9):e022837.

52.Casey BM, Dashe JS, Wells CE, McIntire DD, Byrd W, Leveno KJ, et al. Subclinical hypothyroidism and pregnancy outcomes. Obstet Gynecol. 2005;105(2):239-45. 
تاثير هيبِوتيروئيدى تمت...

53.Chen L-M, Du W-J, Dai J, Zhang Q, Si G-X, Yang H, et al. Effects of subclinical hypothyroidism on maternal and perinatal outcomes during pregnancy: a single-center cohort study of a Chinese population. PloS one. 2014;9(10):e109364.

54.Saki F, Dabbaghmanesh MH, Ghaemi SZ, Forouhari S, Omrani GR, Bakhshayeshkaram M. Thyroid function in pregnancy and its influences on maternal and fetal outcomes. Int $\mathbf{J}$ Endocrinol Metab. 2014;12(4).

55.Fattal-Valevski A, Leitner Y, Kutai M, Tal-Posener E, Tomer A, Lieberman D, et al. Neurodevelopmental outcome in children with intrauterine growth retardation: a 3-year follow-up. J Child Neurol. 1999;14(11):724-7.

56.Leitner Y, Fattal-Valevski A, Geva R, Eshel R, Toledano-Alhadef H, Rotstein M, et al. Neurodevelopmental outcome of children with intrauterine growth retardation: a longitudinal, 10-year prospective study. J Child Neurol. 2007;22(5):580-7.

57.Lipper E, Lee K, Gartner L, Grellong B. Determinants of neurobehavioral outcome in low-birth-weights infants.. Pediatrics 1981;67:502-5.

58.Idris I, Srinivasan R, Simm A, Page RC. Maternal hypothyroidism in early and late gestation: effects on neonatal and obstetric outcome. Clin Endocrinol. 2005;63(5):560-5.

59.Martinez M, Soldevila B, Lucas A, Velasco I, Vila L, Puig-Domingo M. Hypothyroidism during pregnancy and its association to perinatal and obstetric morbidity: a review. Endocrinol Diabetes Nutr. 2018;65(2):107-13.

60.Baydyuk M, Xu B. BDNF signaling and survival of striatal neurons. Front Cell Neurosci. 2014;8:254.

61.Frisca F, Crombie DE, Dottori M, Goldshmit Y, Pébay A. Rho/ROCK pathway is essential to the expansion, differentiation, and morphological rearrangements of human neural stem/progenitor cells induced by lysophosphatidic acid. J Lipid Res. 2013;54(5):1192206.

62.Uesaka T, Nagashimada M, Enomoto H. GDNF signaling levels control migration and neuronal differentiation of enteric ganglion precursors. J Neurosci. 2013;33(41):16372-82.

63. Organization WH. Children and neurodevelopmental behavioural intellectual disorders (NDBID), 51p: World Health Organization; 2013.

64.Li J, Zhao Y, He L, Gao X, Wang X, Xie Y. Influence of subclinical hypothyroidism in pregnancy on the intellectual development of their offspring and analysis of Levothyroxine intervention. J China Med Univ. 2015;44:64-7.

65.Xia Y, Zhou Y, Zong D, Han L, Li X, Chen F. Impact of mental development in offspring by maternal thyroid autoimmunity and subclinical hypothyroidism in pregnancy. Journal of Clinical and Experimental Medicine. 2015;14:670-2. 